lytic activity. Such changes have been interpreted as a physiological development to provide for effective haemostasis and preservation of the maternal blood volume during parturition (Bonnar et al., 1971). The increased levels of coagulation factors associated with pregnancy have been reported as occurring, in the main, in the third trimester.

In the present study factors VII and X were found to be increased early in the second trimester. An increase of similar magnitude in the activity of these factors at an unspecified time during the second trimester was reported by Nilsson and Kullander (1967). Already there are reports emphasizing the haemhorragic complications of therapeutic abortion, and it is likely that in some instances defective blood coagulation may be responsible.

The increase in the activity of factors V, VIII, and X which were found during induction of abortion in mid-trimester pregnancy by extra-amniotic prostaglandin $\mathrm{F}_{2} \alpha$ indicates that activation of the coagulation system is taking place. In particular the increase of factor X may be due to the escape of thromboplastin substances from the placental site during uterine contractions and especially at the time of placental separation. It has been shown in hamsters that thromboplastin material enters both the maternal and fetal circulation during placenta separation (Brown and Stalker, 1969). During placental separation at term in normal pregnancies increased levels of coagulation factors V and VIII have been found in both peripheral and uterine blood (Bonnar et al., 1970). Stander et al. (1971) suggested that induction of abortion by intra-amniotic injection of hypertonic saline initiates disseminated intravascular coagulation. They reported more extensive changes than were found in the present study.

It is of interest that virtually no changes in the coagulation system were found during termination of early pregnancy by vacuum aspiration. It seems, therefore, that when pregnancy is terminated in the mid-trimester, whether by hypertonic saline instillation or by extra-amniotic prostaglandin, coagulation system changes in the circulating blood take place. These are most probably related to the physiological changes which have taken place in the haemostatic system in the second trimester. Coagulation changes associated with abortion will establish a vulnerable state for intravascular clotting and thromboembolic complications. It is likely, therefore, that in susceptible patients termination of pregnancy after the first trimester may give rise to such complications as defective haemostasis or thromboembolic complications.

We wish to thank the consultant staff of the division of obstetrics and gynaecology for allowing us to study patients under their care. We gratefully acknowledge gifts of prostaglandin $F_{2} \alpha$ from Dr. R. Jacomb, of the Upjohn Company.

One of us (M.H.H.B.) was on study leave from the department of obstetrics and gynaecology, Al Azhar University, Cairo, and was in receipt of a Ford Foundation Fellowship. This investigation has been supported in part by the Agency for International Development contract No. AID/Csd 2837 (granted to K.H. and M.P.E.).

We thank Mr. M. Haddon and Mrs. J. Fairweather for expert technical help.

Requests for reprints should be sent to Dr. M. H. H. Badraoui, Al Azhar University, Cairo, Egypt.

\section{References}

Bell, W. N., and Alton, H. G. (1954). Nature, 174, 880.

Biggs, R., Eveling, J., and Richards, G. (1955). British fournal of Haematology, $1,20$.

Bonnar, J., Davidson, J. F., Podgeon, C. F., McNicol, G. P., and Douglas, A. S. (1969). British Medical fournal, 3, 137.

Bonnar, J., McNicol, G. P., and Douglas, A. S. (1971). In Scientific Basis of Obstetrics and Gynaecology, ed. R. R. Macdonald, London, Churchill.

Bonnar, J., Prentice, C. R. M., McNicol, G. P., and Douglas, A. S. (1970). British Medical fournal, 2, 564.

Brown, L. J., and Stalker, A. L. (1969). Microvascular Research, 1, 403.

Denson, K. W. (1961). Acta Haematologica, 25, 105.

Merskey, C., Kleiner, G. J., and Johnson, A. J. (1966). Blood, 28, 1.

Nilsson, I. M., and Kullander, S. (1967). Acta Obstetricia et Gynecologica Scandinavica, 46, 273.

Quick, A. J. (1966). Haemorrhagic Disease and Thrombosis, p. 391. Philadelphia, Lea and Febiger.

Stander, R. W., Flessa, H. C., Glueck, H. I., and Kisker, C. T. (1971). Obstetrics and Gynaecology, 37, 660 .

Stefanini, M., and Dameshek, W. (1962). Haemorrhagic Disorders, p. 451. New York, Grune and Stratton.

\title{
Problem of the Old and the Cold*
}

\section{R. H. FOX, R. MacGIBBON, LOUISE DAVIES, PATRICIA M. WOODWARD}

British Medical fournal, 1973, 1, 21-24

\section{Summary}

A pilot winter study of body temperatures using new measuring techniques was tested on 72 volunteers aged 65 or more living in Portsmouth. The body temperatures were related to their environmental temperature and living conditions. No case of serious hypothermia was found, but the study confirms that elderly people have

* This work was one of two pilot studies preceding a major study on 2,000 elderly people in 1972. It is hoped to publish the results of the main study, which was a collaboration between the Centre for Environmental Studies (Professor D. Donnison and Mr. M. Wicks), the Medical Research Council (Dr. R. H. Fox and Miss P. M. Woodward), University College Hospital
(Dr. A. N. Exton-Smith), and the Royal Free Hospital (Dr. M. F. Green), early in 1973 .

Division of Human Physiology, National Institute for Med:cal Research, London NW3 6RB

R. H. FOX, M.B., M.R.C.S., Member of Scientific Staff

R. MACGIBBON, M.B., B.S., Associate Research Worker

PATRICIA M. WOODWARD, B.Sc., Member of Scientific Staff

Queen Elizabeth College, London W8

LOUISE DAVIES, B.SC., Head of Geriatric Nutrition Unit lower body temperatures and suggests that the coldest individuals tended to be the least aware of discomfort from the cold; this may well place them "at risk" for developing hypothermia.

\section{Introduction}

The incidence of hypothermia of the elderly is uncertain, with estimates varying from the hundred or so returns on the Registrar General's death certificates to over 20,000 deaths annually (Taylor, 1964). A committee of the Royal College of Physicians (1966) estimated that in a three-month winter period in Britain there could be 9,000 hospital admissions with hypothermia (rectal temperature $<35^{\circ} \mathrm{C}$ ).

Mouth temperature was advocated for the diagnosis of hypothermia (a deep body temperature below $35^{\circ} \mathrm{C}\left(95^{\circ} \mathrm{F}\right)$ ) by a special committee for the British Medical Association (1964). In the winter survey undertaken by the Society of Medical Officers of Health (1968), $11.4 \%$ of all mouth temperatures of elderly people living at home were $35^{\circ} \mathrm{C}$ or below. In another similar survey (Williams, 1968), $5 \cdot 1 \%$ of mouth temperatures were below $35^{\circ} \mathrm{C}$ and $17 \cdot 8 \%$ were below $35.5^{\circ} \mathrm{C}\left(95.9^{\circ} \mathrm{F}\right)$. Many of the 
elderly people with mouth temperatures at or below $35^{\circ} \mathrm{C}$ did not appear to be ill. Reliable measurement of deep body temperature can be made by using a rectal thermometer, but this is unsuitable for large surveys. An alternative technique based on urine temperature has been shown to give a good measure of deep body temperatures (Fox et al., 1971).

There is also uncertainty about the importance of endogenous and exogenous factors in the causation of hypothermia of the elderly. This study was therefore designed with two aims: to test the new urine temperature technique in a population survey; and to measure the mouth, urine, and hand temperatures of a group of elderly people living at home and to investigate their relation to living conditions and environmental temperatures.

\section{Subjects and Methods}

\section{POPULATION SAMPLE}

The subjects were chosen from the 300 people over 65 years receiving the "meals-on-wheels" service in Portsmouth in 1971 and who had previously taken part in a nutrition survey (L. Davies, unpublished data). One hundred were selected for the nutrition survey to provide a sample stratified by age and sex. For the hypothermia study, eight were unwilling to participate and data were too incomplete on a further 20 . Of the remaining 72, eight were men and 17 were women under 75 years of age, and 12 were men and 35 were women over 75 years. The average age was 77 years (men 76 and women 78 ) ranging from 65 to 91 . The mean height for men was $167 \cdot 7$ $\mathrm{cm}$ and their weight $63.7 \mathrm{~kg}$ compared with the women's mean height of $156 \cdot 1 \mathrm{~cm}$ and weight of $59 \cdot 7 \mathrm{~kg}$.

\section{SURVEY TECHNIQUE}

The survey took place between 18 January and 10 March 1971. Each subject was first visited by a team member who explained the nature of the study. If the subject agreed to participate a detailed questionnaire on the home heating arrangements and general circumstances was completed. A nurse specially trained for the temperature measuring technique subsequently called on two occasions on consecutive days, with 24 hours between visits. On the first visit the nurse measured temperatures and she asked the subject to use a Uritemp bottle. If this was not immediately possible, the bottle was left for the subject to use as soon as convenient. A second bottle was left for use the following day. On the second visit all the measurements were repeated and the nurse collected the bottles.

\section{TEMPERATURE MEASUREMENTS}

Sublingual, hand, and urine temperatures were recorded using mercury-in-glass, low-reading, clinical thermometers calibrated to $\pm 0.05^{\circ} \mathrm{C}$. The techniques were described by Fox et al. (1971) but are briefly as follows.

Mouth Temperature.-The thermometer was positioned sublingually with the mouth closed for five minutes.

Hand Temperature.-The subject held a short rod of expanded polystyrene with the low-reading clinical thermometer located in a shallow groove along one side. The bulb of the thermometer was thus pressed against the middle of the palm for five minutes. This gives the deep tissue temperature rather than the more transient skin temperature.

Urine Temperature.-The Uritemp bottle consisted of a onelitre plastic bottle fitted with a plastic funnel to direct the urine flow over the bulb of the clinical thermometer. The bottle was calibrated for volumes of $50,100,150$, and $200 \mathrm{ml}$. Laboratory tests have shown the device to be accurate with volumes of 100 $\mathrm{ml}$ or more and to give results within $\pm 0 \cdot 2^{\circ} \mathrm{C}$ with volumes between 50 and $100 \mathrm{ml}$. The women's bottle was similar to the men's except for a wider neck, and both were equipped with handles. (The device has since been simplified and improved by the use of a rigid funnel).

Environmental Temperatures.-The room and external air temperatures were measured using a standard whirling hygrometer. In addition, maximum and minimum thermometers were used to record the temperatures in the bedroom and living room between the first and second visits. They were positioned to give readings representative of the lived-in areas.

Thermal Comfort Votes.-The nurse elicited the subject's assessment of their general and hand thermal comfort. A fivepoint scale was used for general comfort: "Do you feel ..." (0) too cold, (1) on the cool side, (2) comfortable, (3) on the warm side, (4) too warm. A three-point scale was used for hand comfort: "Do your hands feel ..." (0) cold, (1) on the cool side, (2) comfortably warm.

Weather Conditions.-The weather during the survey was a little milder than the average over the last 25 years. Average air temperatures recorded at Thorney Island meteorological station were $+0.7^{\circ} \mathrm{C}$ for the first two months and $-1.7^{\circ} \mathrm{C}$ for the third.

\section{Results}

\section{BODY TEMPERATURES}

The mean mouth, urine, and hand temperatures are set out in table I for the two sexes. There was no significant sex difference and so the results were pooled for subsequent tests. The distributions of mouth, urine, and hand temperatures are set out in the chart.

TABLE I-Mean ( \pm S.D.) Mouth, Urine, and Hand Temperature $\left({ }^{\circ} \mathrm{C}\right)$ by Sex. No. of Measurements is in Parentheses.

\begin{tabular}{|c|c|c|c|c|}
\hline \multirow{2}{*}{\multicolumn{2}{|c|}{ Group }} & \multicolumn{3}{|c|}{ Temperature $\left({ }^{\circ} \mathrm{C}\right)$} \\
\hline & & Mouth & Urine & Hand \\
\hline $\begin{array}{l}\text { Men } \\
\text { Women } \\
\text { Both } \quad \ldots\end{array}$ & $\begin{array}{l}. \\
\because .\end{array}$ & $\begin{array}{l}36 \cdot 0 \pm 0.6(40) \\
36 \cdot 2 \pm 0.6(102) \\
36 \cdot 1 \pm 0.6(142)\end{array}$ & $\begin{array}{l}36.3 \pm 0.7 \text { (39) } \\
36.4 \pm 1.0(89) \\
36.4 \pm 0.9(128)\end{array}$ & $\begin{array}{l}31 \cdot 0 \pm 3 \cdot 5(40) \\
31 \cdot 5 \pm 3 \cdot 4(101) \\
31 \cdot 4 \pm 3 \cdot 4(141)\end{array}$ \\
\hline
\end{tabular}

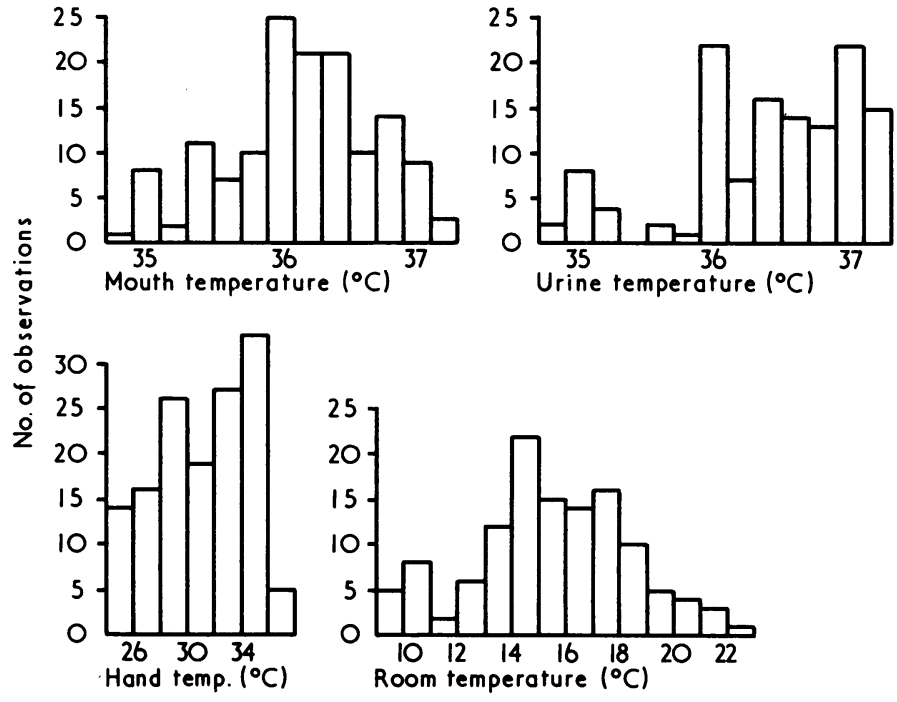

Frequency distributions of body temperatures and room temperatures $\left({ }^{\circ} \mathrm{C}\right)$.

There was only one mouth temperature below $35^{\circ} \mathrm{C}$ (table II), eight readings on seven subjects were at $35^{\circ} \mathrm{C}(6.3 \%$ of readings), and $22(15.5 \%)$ readings were below $35.5^{\circ} \mathrm{C}$ defined as a "low" body temperature by Williams (1968). Only one of these "low" mouth temperatures was recorded in a room with the air temperature exceeding the $18 \cdot 3^{\circ} \mathrm{C}$ limit recommended by the 

TABLB II-Body and Room Temperatures $\left({ }^{\circ} \mathrm{C}\right)$ and Comfort Votes for all Sub-
jects with One or More Mouth Temperature Measurements at $35^{\circ} \mathrm{C}$ or below. Comfort Votes 1 = "On the Cool Side," 2 = "Comfortable."

\begin{tabular}{|c|c|c|c|c|c|c|c|c|}
\hline \multirow{2}{*}{ Sub- } & \multirow{2}{*}{ Sex } & \multirow{2}{*}{ Time } & \multicolumn{4}{|c|}{ Temperature $\left({ }^{\circ} \mathrm{C}\right)$} & \multirow{2}{*}{$\frac{\text { Comfort }}{\text { Hand }}$} & \multirow{2}{*}{$\frac{\text { Votes }}{\text { Body }}$} \\
\hline & & & Mouth & Urine & Hand & Room & & \\
\hline $\begin{array}{r}9 \\
10 \\
36 \\
44 \\
80 \\
90 \\
100\end{array}$ & $\begin{array}{l}\text { M. } \\
\text { F. } \\
\text { M. } \\
\text { F. } \\
\text { F. } \\
\text { F. } \\
\text { F. }\end{array}$ & $\begin{array}{l}\text { A.M. } \\
\text { P.M. } \\
\text { A.M. } \\
\text { P.M. } \\
\text { A.M. } \\
\text { P.M. } \\
\text { A.M. } \\
\text { P.M. } \\
\text { A.M. } \\
\text { P.M. } \\
\text { P.M. } \\
\text { A.M. } \\
\text { P.M. }\end{array}$ & $\begin{array}{l}35 \cdot 0 \\
35 \cdot 0 \\
35 \cdot 0 \\
36.0 \\
34 \cdot 0 \\
35 \cdot 0 \\
36 \cdot 0 \\
35 \cdot 0 \\
35 \cdot 0 \\
35 \cdot 4 \\
35 \cdot 0 \\
36 \cdot 2 \\
35.4 \\
35.0\end{array}$ & $\begin{array}{l}35 \cdot 0 \\
36.0 \\
36 \cdot 0 \\
36 \cdot 0 \\
35.3 \\
36.0 \\
\vdots \\
36 \cdot 2 \\
36.8 \\
36 \cdot 6 \\
36 \cdot 4 \\
36.4 \\
37 \cdot 4\end{array}$ & $\begin{array}{l}26 \cdot 0 \\
29 \cdot 0 \\
29.0 \\
29 \cdot 0 \\
26.0 \\
30.2 \\
34 \cdot 4 \\
32.4 \\
27.0 \\
25 \cdot 0 \\
29 \cdot 2 \\
31 \cdot 0 \\
30.8 \\
28.0\end{array}$ & $\begin{array}{r}14.0 \\
15.0 \\
14.0 \\
14.0 \\
10.2 \\
15.0 \\
22.0 \\
23.0 \\
11.0 \\
13.0 \\
17.0 \\
17.0 \\
9.0 \\
15.0\end{array}$ & $\begin{array}{l}1 \\
2 \\
1 \\
1 \\
1 \\
2 \\
2 \\
1 \\
2 \\
2 \\
1 \\
1 \\
1 \\
1\end{array}$ & $\begin{array}{l}1 \\
2 \\
1 \\
1 \\
1 \\
2 \\
2 \\
2 \\
2 \\
2 \\
1 \\
2 \\
1 \\
2\end{array}$ \\
\hline
\end{tabular}

-Urine temperature measurement impossible because of incontinence.

Parker Morris report on council housing (Ministry of Housing and Local Government, 1961).

Hand temperatures were frequently low with 14 recordings $(10 \%)$ at $26^{\circ} \mathrm{C}$ or below. The mean mouth temperatures $\left(35.8^{\circ} \mathrm{C}\right)$ of the subjects with the cold hands were not, however, significantly different from the means for the whole sample; this indicates that these subjects were thermoregulating normally and maintaining their deep body temperatures by peripheral vasoconstriction but were clearly "cold stressed."

There were significant correlations between hand and mouth temperatures $(P<0.001)$, and mouth and room temperatures $(P<0.01)$, but there was no correlation between hand and room temperatures.

The urine temperatures cannot be compared directly with the hand and mouth measurements because they were frequently obtained at a different time of day. The Uritemp measurements, however, did prove of great value in determining whether subjects with low mouth temperatures were actually hypothermic.

\section{SEVEN LOWEST MOUTH TEMPERATURES}

The body and room temperatures recorded on the seven subjects with one or more mouth temperatures at $35^{\circ} \mathrm{C}$ or below are set out in table II. In four subjects (Nos. 10, 80, 90, and 100), the Uritemp measurement of $36^{\circ} \mathrm{C}$ or higher positively excluded the presence of hypothermia. Urine temperature measurement was impossible for one subject (No. 44) because of incontinence, but the relatively high hand temperature of this subject strongly suggests a failing temperature regulation with an inadequate vasoconstrictor response; fortunately she was living in a warm environment. The two remaining subjects (Nos. 9 and 36) had both mouth and deep body temperatures close to the hypothermic level early in the morning. They should clearly be regarded as "at risk," and it may well be significant that subject 36 was living in a very cold dwelling. The mean hand temperature of this group, excluding subject $36\left(28.4^{\circ} \mathrm{C}\right)$, is below the level $\left(31.4^{\circ} \mathrm{C}\right)$ for the population sample as a whole, and the average room temperature of $13.7^{\circ} \mathrm{C}$ compares with $15.9^{\circ} \mathrm{C}$ for the whole sample. Finally, it is particularly striking that half of the recorded comfort votes on general feeling were "comfortable" and similarly one-third of the votes for the hands.

RELATION BETWEEN 72 SUBJECTS' ASSESSMENTS OF WARMTH AND THEIR BODY TEMPERATURES

No subject reported a general feeling of "too cold" or "too warm" and there were only three reports of feeling "on the warm side." There were 37 occasions (27\%) when the subjects felt themselves to be "on the cool side" and the hand and mouth temperatures on these occasions were significantly lower than when the subjects felt themselves to be "comfortable" (table III). On 52 occasions $(37 \%)$ the subjects felt their hands were "on
TABLE III-Hand and Mouth Temperatures $\left({ }^{\circ} \mathrm{C}\right)$ Correlated roith the Subjects' General Body and Hand Thermal Comfort Votes.

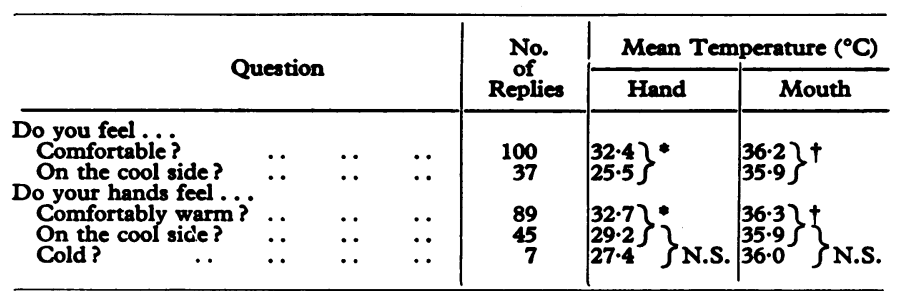

Difference between temperatures $P<0.001$.

$\stackrel{+}{\text { N.S. }}<\mathbf{0}=$ Not significant.

the cool side" or "cold." The mean hand and mouth temperatures of the subject on these occasions were significantly lower than when they judged their hands to be comfortably warm.

\section{ROOM TEMPERATURES}

The distribution of living room temperature at the time of the nurses' visits is given in the chart. It is clear that many of the rooms were much too cold for comfort, and on 100 occasions $(81.3 \%)$ the rooms were below the Parker Morris limit of $18 \cdot 3^{\circ} \mathrm{C}$. Altogether, 70 of the readings $(57 \%)$ were at or below $16^{\circ} \mathrm{C}$, the minimum temperature for working areas specified in the Offices, Shops and Railways Act (1963). The maximum and minimum temperatures recorded for the living rooms confirmed the generally low temperatures set out above. For $20(29 \%)$ of the bedrooms, the minimum was $10^{\circ} \mathrm{C}$ or less; it is of course possible that some of these temperatures occurred in the daytime.

\section{RELATION OF "LIFE SITUATION" WITH OTHER MEASUREMENTS}

In order to find out how body temperatures correlate with factors in the "life situation," the sample was divided into three groups by mouth temperature as follows: $(1)<35.5^{\circ} \mathrm{C}$ (low) 17 subjects; (2) $>35.5^{\circ} \mathrm{C}$ but $<36.5^{\circ} \mathrm{C}$ (normal) 31 subjects; and (3) $>36.5^{\circ} \mathrm{C}$ (high) 24 subjects. The subjects were classified in this way as it is the most common temperature measurement made by a doctor. The equivalent urine, hand, and room temperatures $\left({ }^{\circ} \mathrm{C}\right)$ for the three groups were: urine 36.3 (low), 36.4 (normal), 36.9 (high); hand 28.6 (low), 31.5 (normal), 33.3 (high); room 14.4 (low), 15.2 (normal), 17.5 (high). Many factors in the "life situation" and the subject's

TABLE IV-Relation of "Life Situation" with Mouth Temperatures for. All Subjects, "Low" Temperature Group, "Normal" Temperature Group, and "High" Temperature Group

\begin{tabular}{|c|c|c|c|c|}
\hline \multirow[b]{2}{*}{ Item } & \multicolumn{4}{|c|}{ Percentage of Positive Replies } \\
\hline & $\underset{\text { Subjects }}{\text { From All } 72}$ & \begin{tabular}{|c|c}
17 \\
"Low" Body \\
Temperature
\end{tabular} & $\begin{array}{c}31 \\
\text { "exmal" } \\
\text { Body } \\
\text { Temperature }\end{array}$ & $\begin{array}{c}24 \\
\text { "High" Body } \\
\text { Temperature }\end{array}$ \\
\hline 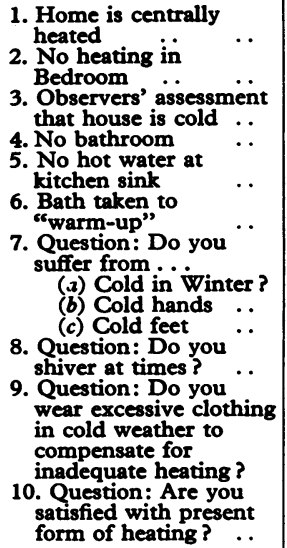 & $\begin{array}{r}15 \\
24 \\
10 \\
24 \\
33 \\
6 \\
\\
54 \\
42 \\
33 \\
15\end{array}$ & $\begin{array}{r}6 \\
47 \\
24 \\
35 \\
53 \\
0 \\
\\
47 \\
53 \\
29 \\
0\end{array}$ & $\begin{array}{r}19 \\
19 \\
6 \\
23 \\
32 \\
6 \\
\\
55 \\
32 \\
35 \\
16\end{array}$ & $\begin{array}{r}17 \\
13 \\
4 \\
17 \\
21 \\
8 \\
\\
58 \\
46 \\
33 \\
25\end{array}$ \\
\hline
\end{tabular}


reactions elicited in the questionnaire, although important, proved difficult to define or measure accurately-for example, degree of isolation. This explains the selection given in table IV. It must be stressed that the population studied was known to be in need of assistance because they were receiving the meals-onwheels service.

For this type of study the population sample was clearly too small to establish many meaningful statistical differences, but it has revealed certain trends of considerable interest. There are strong indications of a relation between "low" body temperatures and $(a)$ the inadequacy of heating arrangements (items 1,2 , 3 , and 4 in table IV); (b) the lack of basic amenities (items 2, 4, and 5); and (c) the subject's response to certain aspects of the "life situation" (items 6, 7, 8, 9, and 10). Here it seems that the "low" temperature group are, if anything, less aware of being cold in winter $(7 a)$ and having cold feet $(7 c)$, but much more aware of cold hands $(7 b)$ than the other groups. None of the "low" group thought they ever shivered (8), they did not think they had to wear excessive clothing (9), nor did they express greater dissatisfaction with the heating arrangements (10).

In the earlier nutrition survey all the subjects had weighed and recorded their diet for seven consecutive days. The average calorie intake-and the recommended daily allowance in relation to each subject was calculated using the food tables prepared by the D.H.S.S. (1969). The differences between the recorded and recommended daily allowances for the three groups were: "low" temperature $-56 \mathrm{Kcal}$; "normal" temperature -121 Kcal; "high" temperature $-214 \mathrm{Kcal}$. The "high" group were eating significantly $(P<0.05)$ less than the recommended allowance. Other differences were not significant, nor were the differences between the groups, but they suggest that the lower the body temperature the more food was eaten. This could be a factor in helping to avoid an even lower body temperature.

\section{Comment}

This survey agrees with many previous reports and the intensive study by Salvosa et al. (1971) in showing a high frequency of low mouth temperatures in elderly people living at home in the winter. Altogether, $24 \%$ of the subjects had a "low" mouth temperature $\left(<35.5^{\circ} \mathrm{C}\right)$ and the average for the 72 subjects was only $36 \cdot 1^{\circ} \mathrm{C}$. The average deep body temperature of these elderly people, measured by the urine technique, was also lower $\left(36.4^{\circ} \mathrm{C}\right)$ than is normal for younger age groups, but no case of serious hypothermia $\left(<35^{\circ} \mathrm{C}\right)$ was found. However, old people with a lower body temperature than younger individuals have less body heat to lose before the deep temperature will reach the hypothermic level and therefore hypothermia can develop more rapidly with exposure to cold.

The "low" mouth temperature group tended to be living in the coldest dwellings with the greatest deficiencies in basic amenities which would help to keep them warm; nevertheless, many of them did not feel they were cold or even shivered and they did not think the heating level was inadequate. This agrees closely with the findings of others and especially Watts (1971). These apparently lower warmth and cold thresholds in some old people, combined with a low environmental temperature in their homes and a reduced safety margin of heat to lose before hypothermia will supervene, would seem to put them especially "at risk." If they become immobilized-for example, falling and injuring themselves-or become further cold exposed for any other reason-for instance, a sudden cold spell and inadequate heating appliances-they are more likely to develop hypothermia.

All the earlier clinical studies on hypothermia (Exton-Smith, 1968) as well as the B.M.A. (1964) and the R.C.P. (1966) reports agree that when the deep body temperature falls below $35^{\circ} \mathrm{C}$ the condition begins to become serious and the mortality rises with the depth of hypothermia. The diagnosis of hypothermia depends on making a reliable measurement of the deep body temperature and for this particular purpose the mouth temperature is inadequate (Fox et al., 1971).

Mouth temperature can be used with confidence to exclude hypothermia, but when the mouth temperature is low, the deep body temperature should be checked either by a rectal measurement or another technique. The Uritemp bottle used in this survey proved acceptable and relatively simple, and it could be used on a wider scale.

During cold weather doctors should be particularly concerned about any elderly patients who tended to have a "low" mouth temperature, are living in poorly heated accommodation, and yet say "they don't feel the cold." These are a group of old people "at risk" of developing hypothermia if for any reason they become immobilized in cold conditions. To avoid missing the diagnosis the wider use of low-reading clinical thermometers has been advocated, but in practice they are rarely used because of their cramped and inconvenient scale. We suggest the standard clinical thermometer should have its scale extended downwards to $33^{\circ} \mathrm{C}$ or $32^{\circ} \mathrm{C}$ which would not mean an excessive cramping of the scale and should make it less likely that low body temperatures will be missed.

We are grateful to Dr. P. G. Roads, Medical Officer of Health, Portsmouth, for the co-operation of his department, to Mrs. K. Hastrop and her colleagues, for the interviews, and to the Gas Council, who helped finance the survey.

We are especially grateful to all the subjects for their willing co-operation.

\section{References}

British Medical Association Memorandum (1964). British Medical fournal, 2, 1255 .

Department of Health and Social Security (1969). Reports on Public Health and Medical Subjects, No. 120. London, H.M.S.O.

Exton-Smith, A. N. (1968). Practitioner, 200, 804

Fox, R. H., Woodward, Patricia M., Fry, A. J., Collins, J. C., and MacDonald, I. C. (1971). Lancet, 1, 424.

Ministry of Housing and Local Government (1961). Parker Morris Committee Report. London, H.M.S.O.

Offices, Shops and Railways Act (1963). London, H.M.S.O.

Royal College of Physicians of London (1966). Report of Committee on Accidental Hypothermia.

Salvosa, Carmencita, B., Payne, P. R., and Wheeler, Erica F. (1971). British Medical fournal, 4, 656 .

Society of Medical Officers of Health Hypothermia Sub-Committee of the Welfare Group (1968). Public Health (London), 82, 223.

Taylor, G. (1964). Practitioner, 193, 761.

Watts, A. J. (1971). Environmental Research, 5, 119.
Williams, B. T. (1968). Gerontologia Clinica, 10, 281. 